\title{
Reconstructing Meat Consumption through Biomarker Analyses of Paleofeces
}

Jenna M. Battillo ${ }^{1^{*}}$ and Abigail E. Fisher ${ }^{1}$

Author Addresses: ${ }^{1}$ Department of Anthropology, Southern Methodist University, 3225 Daniel Avenue, Heroy Hall, Room 408, Dallas, TX 75205-1437, USA.

*Corresponding author: jbattillo@smu.edu

Received: May 6, 2015

Published: August 25, 2015

Volume: 6(1):111-113

(C) 2015 Society of Ethnobiology

Abstract: This mini-review outlines three underutilized approaches for studying meat-based biomarkers in archaeological paleofeces that we expect will increase in significance within the field. Myoglobin, stable isotope, and aDNA analyses all have untapped potential to inform meat-based dietary constituents.

Keywords: Paleodietary analysis, DNA, Stable isotope analysis, Myoglobin, Meat consumption, Coprolites, Paleofeces

Paleofeces provide some of the most precise and unambiguous evidence for diet in archaeological research, as they allow researchers to directly identify digested remains of dietary constituents. Furthermore, parasite eggs, human DNA, and other contents of paleofeces can inform about individual health and life histories. Radiocarbon dating can directly link these data to a temporal scale (Jenkins et al. 2012). This review discusses the potential application of three biomarkers found in paleofeces-myoglobin, stable isotopes, and DNA - that can be used to reconstruct meat consumption in the archaeological record.

Several biomolecules can indicate meat consumption, but perhaps the least understood of these is myoglobin. Myoglobin is an oxygen and iron binding protein found exclusively in skeletal and cardiac muscle; therefore, it can only be incorporated into feces by ingestion or due to severe health issues. Myoglobin can often be identified to the genus or species level, and is used in modern food studies to identify the contents of meat products. A groundbreaking archaeological study performed by Marlar and colleagues (2000) used enzyme-linked immunosorbent assay (ELISA) on a cooking pot sherd and a human paleofecal sample from Cowboy Wash Pueblo, Colorado to confirm a suspected case of cannibalism. Both the paleofeces and the cooking pot tested positive for human myoglobin, indicating human muscle tissue had been cooked and consumed. All control samples (including comparative modern human fecal samples, human paleofeces, and ceramics from other contexts) tested negative. From this study, it is evident that future use of myoglobin analysis in paleofecal studies could offer broader insights into animal resources that were incorporated into prehistoric diet.

Recent advances in stable isotope analysis may also allow for dietary reconstruction from paleofeces. Isotopic analysis of paleofeces has not been frequently applied in archaeological studies, but isotope ratios from modern feces show seasonal variability and dietary shifts on a shorter timescale in comparison to the early-life signature of teeth and the long-term signature of bone (Blumenthal et al. 2002; Kuhnle et al. 2013). In contrast to teeth and bone, feces represent only a day or two in the life of the animal (Kuhnle et al. 2013).

Meat consumption is reflected in isotopic signatures based on trophic level enrichments. Carbon becomes fixed in plant tissues and is absorbed by consumers; further up the food chain ${ }^{13} \mathrm{C}$ becomes more enriched relative to ${ }^{12} \mathrm{C}$. Although $\delta^{15} \mathrm{~N}$ can vary between plant species based on nitrogen origin, $\delta^{15} \mathrm{~N}$ primarily rises with increasing trophic levels, so that animals and fish have enriched ${ }^{15} \mathrm{~N}$. However, given the increased complexity of marine food chains, fish are more enriched in ${ }^{15} \mathrm{~N}$ than terrestrial animals, so that the relative representation of fish and meat in diet can be difficult to assess using isotopic studies. A modern dietary study demonstrated that it is possible to differentiate between fish diets and mixed fish and meat diets using stable $\delta^{15} \mathrm{~N}$ and $\delta^{13} \mathrm{C}$ isotopes analyses from fecal material, although the researchers 
were unable to differentiate between purely terrestrialbased meat diets and diets containing meat and fish (Kuhnle et al. 2013). The ability conferred through isotopic analysis of paleofeces to distinguish between terrestrial and marine-based diets holds important implications for human behavioral shifts (e.g., the Neolithic Revolution). Stable isotope analysis can be used to investigate diet and environment directly, but they can also be used in a more indirect way to study cultural practices related to meat consumption, such as changes in animal husbandry (e.g., Fisher and Thomas 2012). Paleofecal analyses of cattle dung and human feces from the same cultural context could link dietary changes in cattle to patterns of human consumption. For example, they can offer a more nuanced view of changes in cattle tending, including changes in seasonality that would likely be missed using bone or teeth. As such, isotopic analyses of fecal material could offer an untapped source of information on diet and cultural treatment of animals for archaeologists.

Digested remains of meat often cannot be identified through visual assessment, so DNA can serve as an invaluable source of information on specific animal resources in diet. Both traditional PCR and high-throughput sequencing have been used in multiple ecological studies of modern animals to identify dietary remains from feces (Deagle et al. 2010; Mallott et al. 2015). Recent advances in highthroughput DNA sequencing technologies allow simultaneous testing for numerous taxa in a single sample while using smaller DNA fragments. These studies have changed the way that ecological and primatological studies of diet are being conducted (e.g., Mallott et al. 2015) and have the potential to contribute similarly to archaeological studies.

Recent archaeological studies have demonstrated that paleofeces often contain analyzable DNA from dietary contents (e.g., Battillo et al. 2014; Poinar et al. 2001). Both Poinar et al. (2001) and Battillo et al. (2014) successfully extracted mitochondrial DNA (mtDNA) using traditional PCR to study animal constituents from archaeological paleofeces in Hinds Cave, Texas and Turkey Pen Ruin, Utah, respectively. The Hinds Cave human paleofeces yielded mtDNA from three animal taxa as well as chloroplast DNA from eight plant families. Several Turkey Pen Ruin paleofeces also yielded mtDNA from mammalian species and one sample tested positive for turkey (Meleagris sp. Linnaeus Phasianidae) mtDNA, as well.
Although there were a number of turkey paleofeces and remains in the same midden, the single positive result for turkey DNA suggests that DNA crosscontamination was unlikely and probably indicates a rare instance of turkey consumption at this site. DNA leaching through sediments has been demonstrated (Haile et al. 2007), but work by Jenkins and colleagues (2012) at Paisley Caves, Oregon showed that leaching is not universal, and demonstrated the validity of associating DNA with a specific paleofecal sample within rock shelter settings.

Biomolecular analyses of paleofeces have been underused in studying diet in archaeology. Myoglobin, stable isotopes, and DNA analyses of paleofeces allow for increased precision in dietary studies through greater species-specific differentiation. Our focus has been on ways to identify the meat portion of human diet, but biomolecular methods should be equally effective when applied to plant remains, and we believe they will greatly enhance archaeological understanding of prehistoric diet.

\section{References Cited}

Battillo, J. M., K. Lupo, J. Mata-Miguez, D. Bolnick, W. D. Lipe and R. G. Matson. 2014. No Bones About It: aDNA Sequencing of Dietary Remains from Human Paleofeces. Paper Presented at the 12th International Conference of Archaeozoology (ICAZ). San Rafael, Argentina. Doi:10.13140/

RG.2.1.4842.2241.

Blumenthal, S. A., K. L. Chritz, J. M. Rothman and T. E. Cerling. 2012. Detecting Intraannual Dietary Variability in Wild Mountain Gorillas by Stable Isotope Analysis of Feces. Proceedings of the National Academy of Sciences of the United States of America 109 (52):21277-21282. Doi:10.1073/pnas.1215782109.

Deagle, B. E., A. Chiaradia, J. McInnes and S. N. Jarman. 2010. Pyrosequencing Faeces DNA to Determine Diet of Little Penguins: Is What Goes in What Comes out? Conservation Genetics 11:2039-2048. Doi:10.1007/s10592-010-0096-6.

Fisher, A. E. and R. Thomas. 2012. Isotopic and Zooarchaeological Investigation of Later Medieval and Post-Medieval Cattle Husbandry at Dudley Castle, West Midlands. Environmental Archaeology 17 (2):151-167.

Doi:10.1179/1461410312Z.00000000013.

Haile, J., R. Holdaway, K. Oliver, M. Bunce, M. Thomas, P. Gilbert, R. Nielsen, K. Munch, S. Y. W. 
Ho, B. Shapiro and E. Willerslev. 2007. Ancient DNA Chronology within Sediment Deposits: Are Paleobiological Reconstructions Possible and Is DNA Leaching a Factor? Molecular Biology and Evolution 24(4):982-989. Doi:10.1093/molbev/ msm016.

Jenkins, D. L., L. G. Davis, T. W. Stafford Jr, P. F. Campos, B. Hockett, G. T. Jones, L. Scott Cummings, C. Yost, T. J. Connolly, R. M. Yohe II, S. C. Gibbons, M. Raghavan, M. Rasmussen, J. L. A. Paijmans, M. Hofreiter, B. M. Kemp, J. L. Barta, C. Monroe, M. T. P. Gilbert and E. Willerslev. 2012. Clovis Age Western Stemmed Projectile Points and Human Coprolites at the Paisley Caves. Science 337 (6091):223-8. Doi:10.1126/science.1218443.

Kuhnle, G. G., A. M. Joosen, C. J. Kneale and T. C. O'Connell. 2013. Carbon and Nitrogen Isotopic Ratios of Urine and Faeces as Novel Nutritional Biomarkers of Meat and Fish Intake. European Journal of Nutrition 52(1):389-395. Doi:10.1007/ s00394-012-0328-2.

Mallott, E. K., R. S. Malhi and P. A. Garber. 2015. Brief Communication: High-Throughput Sequencing of Fecal DNA to Identify Insects Consumed by Wild Weddell's Saddleback Tamarins (Saguinus weddelli, Cebidae, Primates) in Bolivia. American
Journal of Physical Anthropology 156(3):474-481. Doi:10.1002/ajpa.22654.

Marlar, R. A., B. L. Leonard, B. R. Billman, P. M. Lambert and J. E. Marlar. 2000. Biochemical Evidence of Cannibalism at a Prehistoric Puebloan Site in Southwestern Colorado. Nature 407:74-78. Doi:10.1038/35024064.

Poinar, H. N., M. Kuch, K. D. Sobolik, I. Barnes, A. B. Stankiewicz, T. Kuder, W. G. Spaulding, V. M. Bryant, A. Cooper and S. Pääbo. 2001. A Molecular Analysis of Dietary Diversity for Three Archaic Native Americans. Proceedings of the National Academy of Sciences of the United States of America 98(8):43174322. Doi:10.1073/pnas.061014798.

\section{Biosketches}

Jenna M. Battillo is a Ph.D. candidate in the Department of Anthropology at Southern Methodist University. Her research focuses on paleodietary reconstruction using paleofeces from Cedar Mesa, Utah.

Abigail E. Fisher is a Ph.D. student in the Department of Anthropology at Southern Methodist University. Her current research uses stable isotope and zooarchaeological analyses to study mechanisms of state collapse in South Africa. 